\title{
The Challenges of Democratizing News and Information: Examining Data on Social Media, Viral Patterns and Digital Influence
}

\section{Citation}

Wihbey, John P. 2014. The Challenges of Democratizing News and Information: Examining Data on Social Media, Viral Patterns and Digital Influence. Shorenstein Center on Media, Politics and Public Policy Discussion Paper Series, \#D-85 (June 2014).

\section{Published Version}

http://shorensteincenter.org/d85-wihbey/

\section{Permanent link}

http://nrs.harvard.edu/urn-3:HUL.InstRepos:12872220

\section{Terms of Use}

This article was downloaded from Harvard University's DASH repository, and is made available under the terms and conditions applicable to Other Posted Material, as set forth at http:// nrs.harvard.edu/urn-3:HUL.InstRepos:dash.current.terms-of-use\#LAA

\section{Share Your Story}

The Harvard community has made this article openly available.

Please share how this access benefits you. Submit a story.

\section{Accessibility}




\title{
Shorenstein Center on Media, Politics and Public Policy
}

Discussion Paper Series

\#D-85, June 2014

\section{The Challenges of Democratizing News and Information: \\ Examining Data on Social Media, Viral Patterns and Digital Influence}

\author{
By John Wihbey \\ Managing Editor, Journalist’s Resource \\ Shorenstein Center
}

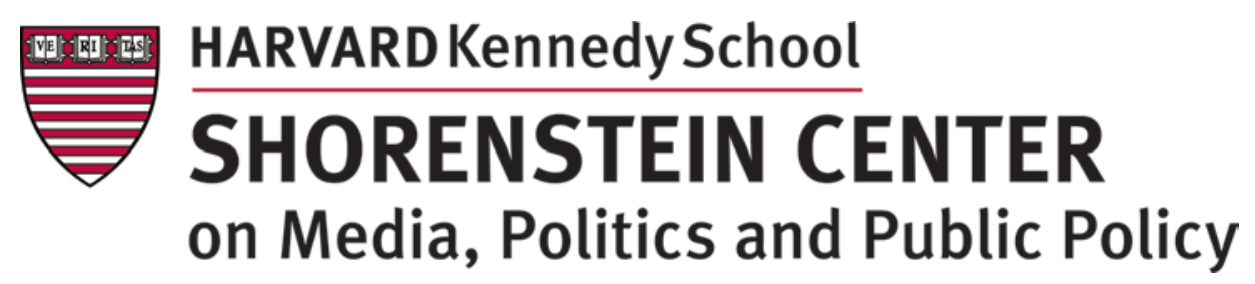

Licensed under a Creative Commons Attribution-NoDerivs 3.0 Unported License. 


\section{Introduction}

Our digitally networked world fuels the dream of the democratization of thought, ideas and flows of information.

Huge networks underpin the dream. Facebook boasts more than a billion users, Twitter has a quarter-billion. The Sina Weibo microblogging platform in China sees nearly 150 million users a month.

Given that Facebook was founded in 2004 and Twitter in 2006, the era of social media is still in its infancy. There are parallels to the periods immediately following the introduction of Gutenberg's printing press in the 15th century and Alexander Graham Bell's telephone in the 19th century, when the full impact of those inventions was not yet clear.

Because of the Web, we have seen amazing examples of "nobodies" becoming "somebodies" overnight, of whiplash-fast events arising in previously obscure corners of the world. We witness instances of super-empowered citizens, viral phenomena, and the seemingly instant coordination of protests and celebrations alike. Memes and hashtags zip and proliferate.

These are the relative "successes" of the digital age; high-profile instances of a democratizing system are frequently the points of emphasis when we talk about the rise of the Web. We seldom discuss the failures and what, on balance, has not changed. But there has been a simmering counter-narrative, one articulated mostly in academic circles and largely ignored in popular discourse. Worries have been mounting for some time about the online world's capacity to change traditional dynamics of access and inequality around news and information.

Citizens may have more pathways to engage with and produce important content, but that does not mean they will use them - or that they will be powerful within these pathways. On the Web an attention arms race is clearly at hand. A "power law" still characterizes how attention is distributed, despite the capacity for open networks to distribute it more equitably, and for more people to focus on diverse sources. There are a few significant winners and many millions who struggle to garner much attention at all.

In his 2008 book The Myth of Digital Democracy, Matthew Hindman of George Washington University shows that the readership of political postings is "orders of magnitude more unequal than the disparities we are used to in voting, volunteer work and even political fund-raising." Further, by some measures, "online audience concentration equals or exceeds that found in most traditional media." 1

These dynamics affect people and organizations of all kinds across the Web. For example, a 2014 study by Trevor Thrall and Diana Sweet of George Mason University and Dominik Stecula of the University of British Columbia analyzed the efforts of 257 human rights organizations to get wider media and general online attention. Because of the "zero-sum nature of public attention," most human rights groups get little media publicity; instead, news coverage heavily favors a few larger organizations with greater resources. And on the Web, the same thing happens: Organizations compete for audience attention through social media. Among the groups studied, the top 10 percent of human rights organizations accounted for 90 percent of YouTube views, 81 percent of Facebook likes and 92 percent of Twitter followers. ${ }^{2}$ 
Still, the information ecosystem overall has changed, as more small publishers have been created. As Internet theorist and Harvard University scholar Yochai Benkler pointed out in his 2006 book, The Wealth of Networks, the system of mutual linking among tight clusters of less-known bloggers and commentators can form an "attention backbone" and build pathways for interesting ideas and statements to find broader audiences. This is part of what Benkler has called the "networked public sphere" and "networked Fourth Estate." 3 Some research indicates that dominant, elite positions within the blogosphere are relatively transient; the masses thus democratically "elect" top blogs with views and clicks. ${ }^{4}$ Likewise, a Twitter hashtag can create an attention backbone, empowering otherwise less-known, less powerful individuals.

More than any prior technology, social media have the possibility of driving this democratization of information even further, undercutting the agenda-setting of large media outlets and their relative control of news and information flows. There are many ways to assess this issue. One way is to examine carefully how people get their news. Another is to look precisely and empirically at how information is flowing across social networking sites and how human behavior may be changing because of this.

This paper brings together media industry data and perspective - from NPR, the Boston Globe and the Wall Street Journal - with a growing body of social science and computational research produced by universities and firms such as Microsoft Research and the Facebook data science team, as well as survey findings from the Pew Research Center. The bulk of the evidence so far complicates any easy narrative, and it very much remains an open question if we can expect a more radically democratized media ecosystem, despite promising early trends and anecdotes. As I review the evidence, I aim to highlight lessons and insights that can help those thinking about and operating in the social media space. I also hope this paper serves as an accessible survey of relevant topics within social science, social network and media scholarship.

\section{Old Habits Revisited}

The ingrained habits of average people seeking and engaging with news and information have not changed as dramatically as some might have expected. Certainly, audiences have fragmented considerably since the Internet's rise in the 1990s and a handful of news broadcasts and daily papers no longer command the mass attention they once did.

A small tier of elite media consumers have adopted omnivorous habits, using Twitter streams, apps and other technological aides to view media across dozens of sources. But these information elites do not represent Americans as a whole. According to the Pew Research Journalism Project, just 8 percent of U.S. adults get news from Twitter. Those who do use the social media platform to get news tend to be highly educated, and about 50 percent of them earn more than $\$ 75,000 \mathrm{a}$ year. ${ }^{5}$

In a 2013 Gallup poll, some 55 percent of Americans said their main sources of news was television (print and radio constituted another 15 percent), and while 21 percent cited the Internet as their go-to source, just 2 percent of those surveyed said social media were a main source of news. ${ }^{6}$ In 2014 the American Press Institute found that still the most popular way by far for people to get news is directly from news outlets (88 percent of survey respondents). The Institute's research did find that social media has become an "important tool" for discovering news -4 of every 10 persons surveyed reported using social media to discover news in the past 
week - but it was only one of many tools, and news consumers seem to vary their method of discovery and access based on the kind of news in question. ${ }^{7}$

Data patterns show halting progress toward a more diversified online audience ecosystem. A Microsoft Research-Carnegie Mellon study tracked 1.2 million Internet users as they surfed some 2.3 billion Web pages from March to May 2013. It found that more than three-quarters of all online news consumption consisted of people accessing stories directly through media websites (79 percent for news stories and 67 percent for opinion pieces.) The researchers, Seth Flaxman, Sharad Goel and Justin M. Rao, conclude that 78 percent of people get the majority of their news online from a single source, while 94 percent get a majority from "at most two outlets." Social media channels accounted for a vanishingly small amount of news consumption - somewhere in the low single digits. ${ }^{8}$

Likewise, in a Pew study of 26 leading news organization sites, 19 of them saw 75 percent or more of their visitors come directly to their site. Most saw "extremely small" traffic from Facebook, with the exception of the digitally native outlet BuzzFeed, which saw 11.3 percent of its traffic come from there. ${ }^{9}$ Even in an international context, social media are not primary pathways for accessing and engaging with news. In a recent study of eight countries across Europe and North America, Rasmus Kleis Nielsen and Kim Christian Schrøder note that "social media at this point still play a relatively limited role as sources of news - less widely used and less important than printed newspapers in all eight countries; that they in some cases play a somewhat larger role as a way of finding news; and that only a minority use them to engage in more participatory forms of news use like sharing, commenting on, or publishing their own stories." 10

Some of this may eventually change as demographics shift. The Reuters Institute's "Digital News Report 2013" found that 38 percent of those under 45 in the United States said they find news through social media, compared to 23 percent for those over $45 .{ }^{11}$ Greater use of mobile devices frequently associated with greater social media use - may help accelerate this trend over the long run. However, the American Press Institute report notes that "even for the youngest adults, age 18-29, social media and the Web in general have hardly replaced more traditional ways of getting the news." ${ }^{2}$

Even the most traditional forms of broadcast seem to be holding steady, albeit in diminished form compared to their mid-20th century dominance. In 2013, the three major evening network news broadcasts actually saw a marginal audience increase, 2.3 percent, putting their aggregate viewership number, 22.6 million, at its highest level since 2008, according to Nielsen figures reviewed by the Pew Research Center. ${ }^{13}$

In a 2014 internal document, the New York Times notes that its homepage traffic has been "declining month after month, for years. Traffic to section fronts is negligible." ${ }^{14}$ This prompted some to declare that the "social web has won," and people are now getting their news more through "push" media - i.e., social streams - as opposed to the traditional "pull” pattern. ${ }^{15}$ This is true to some degree, but as the Times 2014 report notes, less than 10 percent of its overall Web traffic comes through social media. ${ }^{16}$

To address the question of whether the American news audience will ultimately fragment into many news niches, James G. Webster of Northwestern University and Thomas B. Ksiazek of Villanova University studied television and Internet news access patterns across more than 1,000 representative households. They conclude that people get news from a variety of sources, but they 
often still spend most of their time with the same relatively broad-scope, mainstream outlets accessed by many other citizens. Webster and Ksiazek conclude that a "winner-take-all" dynamic is likely to characterize the media universe even in the digital future, as certain outlets have much higher levels of quality and have more socially desirable qualities - serving as common "coins of exchange" among social groups. Further, because algorithmic recommendation engines exert powerful influence in the digital world, "slight leads accumulate advantage," helping to privilege certain news sources time and again. ${ }^{17}$

Social platforms such as Reddit seek to democratize the news agenda and let "the crowd" select what's important, while certain apps and platforms such as Flipboard are providing an algorithmically curated experience that aggregates from across news sources. But these efforts still represent a small portion of overall news consumption and engagement. Countless newsoriented blogs have bloomed, and many have wilted, with most seeing but a trickle of traffic, compared to those run by large media companies. In a 2011 study of how bloggers drive attention during an election cycle, Karine Nahon and a team of researchers at the University of Washington show that a small number of elite sites with the most traffic ignite most of the "viral" content. ${ }^{18}$

Economics also help explain this power-law phenomenon and the skewed distribution of attention in terms of online news. The University of Chicago's Matthew Gentzkow has said that because the fixed costs of producing high-quality news are "still really high," it remains the case that "you end up with, just like in lots of other media markets, a small number of firms control a large share of the [online] market." Thus, a "huge share of news consumption is a small number of big sites." ${ }^{19}$ Much of the best content is still being generated by traditional media, which have the reporting and editing muscle to do what most small organizations and blogs cannot.

Finally, operating here is a basic truth about human nature: In the face of information overload, average news consumers adopt a least-effort selection strategy to cope with the hundreds of media possibilities now on offer. As Nobel Laureate Herbert A. Simon suggested with his idea of "satisficing," we will frequently do the minimum amount of work to achieve a goal in a way that both satisfies and suffices. ${ }^{20}$ In a news and information context, this means looping back to the same trusted outlets. Many citizens might be better off following small blogs or obscure Twitter feeds, but for most, traditional media and easy habits will do.

\section{Not the End of Hierarchy}

The story of the emerging news-information ecosystem is one of metamorphosis as well as of old patterns reasserting themselves in new ways. Prior to the 1990s, our mass communications environment was very much defined by a one-to-many model, or a "broadcast" paradigm. The standard criticism was that citizens encountered information only through mass media and the "influentials" around them who helped them interpret news and information. Among social scientists, this is what's known as the "two-step flow" model of communication. The question now is whether peer-to-peer sharing and viral cascades - a "many-to-many" model — will become the new, dominant paradigm. The hope was that the Internet would provide for more voices as opportunity costs were lowered, and citizens would get broader views on the world. In theory, peer-to-peer network software and technologies have a more democratic character.

W. Lance Bennett of the University of Washington and Jarol B. Manheim of George Washington University have argued that we are moving toward a "one-step flow of communication" paradigm 
because a variety of factors, including the atomization of U.S. civic life - we are increasingly "bowling alone," as Harvard social scientist Robert Putnam has put it - as well as the diminishing importance of leaders and the increasing ability of media to differentiate audiences and tailor content to individuals. The combination of "social isolation, communication channel fragmentation, and message targeting technologies have produced a very different information recipient than the audience members of the Eisenhower era," Bennett and Manheim write. ${ }^{2122}$

Employing a simple three-part typology can help clarify citizens' engagement patterns with information: (1) Media (broadcast) activation, or the streaming from larger platforms to individuals both online and through television, radio, print journals or other forms of mass distribution; (2) Viral (peer-to-peer), or the passing of content between individuals through networks; (3) Hybrid, which combines aspects of media broadcasts and individual peer-to-peer sharing. Discourse on the new media environment frequently focuses on the platform by which content is accessed - Twitter and Facebook, for example - without inquiring into the underlying communications pattern, and whether it is essentially "top down," "bottom up" or some combination.

In general, the media-related and network social science data suggest a mostly hybrid system, with the broadcast model still firmly in place and peer-to-peer networks playing a powerful but limited role alongside.

"We are not seeing the end of hierarchy," says Duncan Watts, a mathematical sociologist and principal researcher at Microsoft Research who has been involved in some of the biggest studies to date on social networks and information diffusion. "We may be seeing the replacement of one hierarchy with another hierarchy. We may be seeing the replacement of one set of gatekeepers with another set of gatekeepers.... But we're certainly not seeing an egalitarian world where everything has the same chance to become known or accessible."23

The general idea that everything is viral now and information is mostly spreading in infectious, "epidemic" patterns is not the case. Leading studies have increasingly found that most content shared online reaches just a few people; most sharing cascades on networks are short and shallow. Truly viral events, featuring large swells of "bottom up" peer-to-peer sharing by crowds, are exceedingly rare; they occur at a rate of perhaps one in a million across content shared online, including news. ${ }^{24}$ Popularity online is thus still strongly associated with broadcast media dynamics, across all platforms, including social media.

Nahon, co-author with Jeff Hemsley of the 2013 book Going Viral, notes that within social media channels the overwhelming majority of viral items are derivatives or copies of, or responses to, content generated by mass-media producers. Numerous research studies support this. Nahon and Hemsley argue that we now have a new tier of "networked gatekeepers" outside of traditional media channels, and their power to promote content is potentially game-changing. But they also allow that the vast majority of people are mostly still "gated" because of the unequal distribution of attention. ${ }^{25}$

Nevertheless, there are important shifts at hand. "What's changed is the number of individuals who have some of that broadcast capability all on their own," says Clay Shirky, a New York University media and technology scholar. "Anil Dash has more Twitter followers than the print circulation of all but three newspapers in the United States. Tim O'Reilly has enough followers to 
start counting them in Gross Ratings Points. So the broadcast pattern remains well represented, but the old broadcast outlets now have real competition." ${ }^{26}$

The expansion of the number of people with broadcast power is hugely important. But how big, precisely, is it? That question remains largely unanswered, though the evidence so far is that we have not yet seen a paradigm shift.

\section{The Special Case: Mass Events}

In event-driven situations, where significant public emergencies and breaking news are driving attention, there is genuinely a chance for peer-to-peer to play a strong role and for messages to "jump" across network hubs, or group clusters, reaching wider circles. Mass attention is funneled, and networks are then wired for transmission.

To take just one concrete example, during the 2012 presidential debates some individuals with otherwise small social networks were suddenly able to reach large followings. Deen Freelon of American University and David Karpf of George Washington University analyzed these Twitter patterns and noted that one Oregon woman, with only about 500 followers, had a single, humorous message that cascaded across the network. Because high-profile network hubs are paying attention to the same event, Freelon says, and social sharing behavior also spikes around events, communications power can shift incrementally to otherwise little-known individuals. ${ }^{27}$

Similarly, Zeynep Tufekci of the University of North Carolina, Chapel Hill, argues that during periods of political unrest situations, where dissidents are combating repressive regimes, certain "networked microcelebrity" activists can capture significant amounts of public attention, pulling some of the power away from traditional media. The Arab uprisings that began in 2011 amply displayed this new phenomenon, which suggests "substantive alterations to the power relations between mass media, formal opposition institutions, and states compared with earlier periods,” Tufekci writes. ${ }^{28}$

But large-scale events are no guarantee of a more democratic communications system. A May 2014 study published in PLoS One analyzed activity from nearly 194,000 Twitter users during major media events in the 2012 presidential election season. Co-authors Yu-Ru Lin of the University of Pittsburgh, Drew Margolin of Cornell University, and Brian Keegan and David Lazer of Northeastern University explored whether these moments of intense shared public attention created a "rising tide" that helped lift up more social media voices, or whether these events simply created "rising stars." Their conclusion was that democracy actually diminishes at such moments. "The beneficiaries of this newfound attention were not distributed throughout users with different numbers of followers," they write, "but concentrated among users with the largest preexisting audiences." ${ }^{29}$

Rare galvanizing events and anomalies aside, there is little evidence yet that peer-to-peer will be the primary, regular pathway that information travels among citizens, as attention proves much too difficult to capture with any certainty. On Facebook alone, some 2.5 million pieces of content are shared every minute. ${ }^{30}$ When news and information does get broad attention on social networks, it is typically through a broadcast medium - a message blasted to thousands or millions who follow a particular Facebook or Twitter feed. In this way, social network platforms appear to be primarily functioning as yet another broadcast outlet - one more television 
channel, so to speak, or a newspaper thrown on one's digital doorstep - and most content is consumed passively on them.

\section{PART I: SOCIAL AND NEWS: DATA PATTERNS}

\section{Evolution and Optimism}

Despite some initial reluctance, mainstream news media are now facilitating the sharing of their content, allowing the audience to begin to perform what the scholar Manuel Castells has called "mass self-communication" and share with their own social networks. ${ }^{31}$

More than 95 percent of news sites now allow users to "share," "like" or "recommend" content on social media channels, according to a March 2014 survey and report from the Engaging News Project at the University of Texas, Austin. ${ }^{32}$ Most major news organizations have dedicated staff overseeing social media. Data science techniques for optimizing "viral" content for sharing on social networks, embodied by the practices of the news site BuzzFeed and Upworthy, an aggregator and content producer, continue to receive increasing amounts of traffic and growing media industry attention. Outlets from the Dallas Morning News to the Daily Beast are "A/B testing” online news content - using initial samples to determine what audiences respond to most strongly. Everything from images to headlines, site design to the color of social buttons, is being tested on consumers to see which attributes have the greatest success on the social web. ${ }^{33}$

"I think that you had an era where portals were dominant, an era where search was dominant," BuzzFeed founder Jonah Peretti has said. "Now we're at the beginning of an era where social is dominant. So digital feels old and has been around for a while. But social, to me, seems like it has more potential both to create new, interesting kinds of monetization and also to be a friend of original reporting in journalism." 34

In a 2014 blog post titled "The Future of the News Business: A Monumental Twitter Stream All in One Place," Netscape founder and technology entrepreneur Marc Andreessen predicts that "with everyone on the Internet" there is an opportunity for the news content market to expand massively in the next five to 10 years, allowing growth in market size of perhaps 100 -fold. ${ }^{35}$

Two years ago, the Pew Research Center estimated that 8.6 percent of all traffic to news sites comes from social media. ${ }^{36}$ More current 2014 figures from the news analytics platform Parse.ly, which tracks data relating to news platforms across the Web, finds that Facebook is accounting

for proportionally more traffic to major news sites in recent months. ${ }^{37}$ This is likely the result of a change in Facebook's algorithm, dating back to August 2013, which seems to be helping news outlets. ${ }^{38}$ In October 2013 Google accounted for 44 percent of traffic referrals, and Facebook accounted for 16 percent. However, the Facebook figure was up 10 percent through January 2014, while Google's share of referrals dropped to 38 percent, according to the Parse.ly data. ${ }^{39}$

Further, the amount of content sharing on Twitter continues to rise among many major news publishers, with ABC News and the New York Times, for example, each seeing more than 1.5 million shares in March 2014 alone. $^{40}$ 
Sarah Marshall, social media editor for the Wall Street Journal, said that she expects some of these social trends to accelerate - and for news site homepages to become less important, as the audience does more filtering - even as the traditional role of news editors remains important:

Editors were once the sole deciders of the news mix readers would access. Now editors plus other people using social networks coupled with algorithms surface top content and help us find stories. I suspect the future will see us all access a highly personalized stream of content created in response to our interests, and that it will be decided by us setting preferences, by people with social communities, and by smart technology. But I also think there will always be an appetite for editorial judgment used to flag up and order the major news stories of the day. ${ }^{41}$

News organizations now regularly distinguish themselves through social media channels during moments of significant breaking news, particularly involving emergency services and public safety, and fulfill their core public service role in an enhanced way. They have begun to play an essential fact-checking and organizing role in the development of real-time, useful knowledge. ${ }^{42}$

Social media also allow for wider and more diverse sourcing. A 2013 representative national survey of journalists by the Indiana School of Journalism found that nearly 60 percent regularly use social media to get story ideas and more than half find sources and gather additional information this way. ${ }^{43}$ There are also examples of great promise at the experimental edge of journalism. One-time NPR social media journalist Andy Carvin spent several years reporting on the Arab Spring revolutions, sourcing information using Twitter. Researchers Alfred Hermida, Seth C. Lewis and Rodrigo Zamith analyzed Carvin's 60,000 tweets from 2010 to 2011, looking at the relative blend of "alternative voices" and elites. They found that among his sources, "nonaffiliated activists accounted for the greatest single share of tweet mentions, overall (35.3 percent) and for Egypt (37.5 percent)." For the scholars, it is evidence of a "new paradigm of sourcing at play." 44

\section{Drilling Down: NPR.org and the Boston Globe}

Individual news outlets, particularly those with strong national or regional reputations, can see robust social media engagement with stories, perhaps suggesting a news future where the audience plays a bigger role in engaging, remixing, commenting and ultimately filtering what's important. However, achieving high levels of social media engagement takes significant effort and resources.

A few outstanding examples show what is possible in terms of high social media engagement. NPR reaches more than 25 million listeners on a weekly basis through its broadcast channels, but its social web presence is also remarkable in size. ${ }^{45}$ According to internal analytics data provided by NPR digital analyst Daniel Frohlich, NPR's Web traffic was nearly 118 million pageviews, or 27 million unique visitors, for the month of February $2014 .{ }^{46}$ This puts it below the likes of Yahoo News and Huffington Post, and just below the New York Times and Fox News websites, which each saw about 31 million unique in average month last year. But NPR's aggregate traffic figures stand well above those of the Washington Post, for example, and they are roughly comparable to those of USA Today. ${ }^{47}$ 
Among the 55 million visits (first-time and returning visitors together) to NPR.org in February 2014, an astonishing 43.2 percent - 23.8 million visits - came through social media channels. NPR has roughly 3.5 million followers on Facebook and 300,000 on Twitter. Of those, about 12.7 million visits - roughly 23 percent of traffic overall - during that time were the result of peer-topeer social sharing either through Facebook, Twitter, Reddit or StumbleUpon (the major sources of social network engagement for NPR.) Breaking down those numbers further, referral traffic from Facebook to NPR.org was an additional 6.1 million visits, meaning that 45 percent of Facebook traffic to NPR was the result of a genuinely peer-to-peer effect. ${ }^{48}$

Within the media industry, NPR is also noteworthy for what many perceive to be forward-looking digital and social media strategies. Because the site is "digitally native" - no print publication preceded it - it provides a look at what social media can accomplish as legacy media transition more fully to Web-first or even Web-only publication.

"NPR's been fortunate to have social-media journalists who put us on Facebook and Twitter early and maintained vigorous presences ever since," says Patrick Cooper, NPR's director of Web and engagement. "We've pushed to make our existing Web and radio audiences aware of what we're doing on social, and we've worked hard to create a distributed footprint that engages new audiences en masse." 49

The NPR numbers are unusual by industry standards - though other digitally native outlets such as Quartz have seen social media drive 30 to 40 percent of their Web traffic - but it is possible that they represent a leading indicator of what other news organizations may see in the years ahead. ${ }^{50}$ Other large, digitally advanced news outlets see significant engagement around their content. In February 2014, the Times saw about 180 Twitter shares per article and 277 shares on Facebook, according to the social media tracking site NewsWhip. During that same period in 2014, Guardian articles earned 94 Twitter shares and 186 shares on Facebook on average for articles posted on social channels. ${ }^{51}$

Outlets with a more regional character also can succeed in the social media sphere. For this research paper, Joel Abrams, senior product manager at the Boston Globe, shared some of his outlet's recent internal data to illustrate the patterns his outlet is seeing. In March 2014, 18.9 percent of traffic for BostonGlobe.com came from social media sites, while 32.9 percent came directly to the site and 27.2 percent came from search. ${ }^{52}$ Abrams notes that, since the April 2013 Boston Marathon bombing, the Globe has seen enhanced social traffic, as its follower base on Facebook and Twitter expanded enormously.

"A century ago, newspapers posted headlines in the windows of their newsrooms to attract passersby," Abrams notes. ". "These days, the crowds are on Facebook and Twitter, and we need to get our headlines out in front of those users. It does take time and effort to engage with social media in a thoughtful and effective way, but we view it as a crucial way to meet our readers (and potential readers) where they are and get some of their attention and clicks.”54

Among the top 50 stories in March 2014 based on social traffic referrals, a wide variety of Globe articles saw half of their views or more come from social channels - a story about the death of firefighters; a Sunday feature about learning in old age; a controversy relating to the New England Patriots. A snapshot of that metro daily's social media referral traffic patterns reveals real diversity in terms of its social audience's consumption preferences. ${ }^{55}$ 
But social sharing may also be dependent on the goals of social media companies themselves. While Cooper notes that NPR has aggressively promoted its social presence, he also acknowledges that some of these huge traffic numbers, particularly from Facebook, are not entirely their own doing. "Facebook's late-2013 algorithm change benefited us and many other news organizations greatly," he says. "We loved this change but certainly didn’t expect it."

Given that traffic can swing wildly based on technical decisions made by major social media companies, the future of news and networks is unpredictable. "Where the numbers go next is harder to say," Cooper continues. "[N]ews organizations need to stay hyper-aware of how both the social platforms and their own sites’ traffic trends are continuing to change." 56

It is also worth noting the explosive power of social media for certain "hot" news stories for NPR.org. Indeed, among the site's top 10 posts during February 2014, Facebook played an outsize role in driving traffic. For example, the most popular post in February - featuring a debate over evolution and creationism - derived 78.8 percent of its traffic from social networks $(843,000$ out of 1.1 million pageviews overall). This also has an important temporal dimension, as internal NPR data show how over a three-day period, top stories can be in effect be "kept alive" by Facebook and social media, which circulate the story long beyond its initial publication. And in the case of NPR's most popular content, Facebook in particular becomes a kind of "third leg" of the organization, operating as a peer to the broadcast and traditional web operations. ${ }^{57}$

\section{Emerging Realism}

Still, not all newsrooms have completely embraced social media. University of Southern California researcher Mike Ananny recently analyzed the social media policies of eight leading news organizations and concluded:

[N]ews organizations are adopting utilitarian, defensive, and fundamentally conservative relationships to audiences - continuing to seek freedom from readers. When news organizations do use social media to meet audiences, it is to increase online traffic, source information more efficiently, and stay on top of technological trends. Staff are warned against using social media in ways that conflict with organizational priorities, reveal the details of internal news work, rely upon social media privacy protections, or upend norms of objectivity. ${ }^{58}$

Henry Jenkins, also at USC, has advocated producing "spreadable media" that is deliberately designed to break out of broadcast, one-to-many, silos. "News sites which prevent the sharing of such content amongst readers may look like ways to protect the commercial interest of that content," Jenkins has said, "but in fact, they kill it, destroying its value as a cultural resource within networked communities, and insuring that the public will look elsewhere for news that can be spread." 59

Research- and data-based reports have recently introduced a note of qualification - even pessimism - about the extent to which social media channels positively influence and enhance consumption of and exposure to news. If this is true, it suggests that editors and mainstream outlets will continue to dominate in the area of agenda-setting.

For example, the Pew Research Journalism Project's March 2014 report, "Social, Search and Direct: Pathways to Digital News," which analyzed comScore data on 26 of the most popular news 
sites, concluded that users who access a site directly rather than through social media engage with news content nearly three times longer: On a given news site, direct users average 4.6 minutes, compared to just 1.7 minutes by users who enter through Facebook link ${ }^{60}$ Another Pew report, issued in October 2013, found that most news is consumed through Facebook only "incidentally," and just 22 percent of those surveyed reported that Facebook is a useful way of getting news. ${ }^{61}$

NYU's Shirky says this is not surprising:

I imagine those trends will largely stay as they are. People who are clicking on links on social media are in a social context, whereas people who go directly to a news site have in mind something more solitary and focused. By way of analogy, if we had had good stats about magazine reading in doctor's offices versus home subscribers, I think we would have seen the same patterns, for similar reasons. ${ }^{62}$

Survey research generally shows that people have low levels of trust in news they find through social channels; comparatively speaking, most consumers have much higher levels of trust in news they get directly from outlets.

Further, a March 2014 article in Time magazine by Tony Haile, the CEO of Chartbeat, a data analytics company that serves and has access to the internal data of many thousands of media organizations, cast further doubt on the relative strength of social media channels to substantially increase traffic or engagement. Haile asserts that "among articles we tracked with social activity, there were only one tweet and eight Facebook likes for every 100 visitors.” Many digital media practitioners have conventionally believed that the sharing of content promotes more engagement. Based on an analysis of 10,000 articles, Haile writes, there is "no relationship whatsoever between the amount a piece of content is shared and the amount of attention an average reader will give that content." ${ }^{63}$ Upworthy has also found that visitors arriving through Google search spend more time on the site compared to visitors who come through Twitter. ${ }^{64}$

Reuters media and financial columnist Felix Salmon, among others, has suggested that the sites currently perfecting content optimization for social sharing, such as BuzzFeed and Upworthy, may run into trouble with platforms such as Facebook. ${ }^{65}$ Social media platform administrators, who can change their settings at will, may ultimately feel that clever headlines and optimization techniques are simply a way of gaming algorithms and spamming users. There may be a finite limit to optimizing news content for social channels - and not an infinite, ever-growing path to rewards. A May 2014 post by Facebook product manager Mike Hudack criticizing the current state of news media content set off a wide-ranging media debate about how algorithms may be negatively affecting the level of quality of news more generally. ${ }^{66}$ This all suggests a deeply unsettled set of dynamics between social media platforms and news media companies.

Both Chartbeat and Upworthy have begun exploring how to remedy some of the social mediaassociated patterns that suggest very "thin" engagement with content. They want to move past the conventional race for high volumes of visitors and web traffic and focus more on measures related to the "attention web." This would mean emphasizing new measures such as "attention minutes" or "engaged time," and de-emphasizing "click-through rates" and other performance measures that center on volume. ${ }^{67}$ 
There has also been a vast amount of hype around the possibilities of "social TV" and the phenomenon of "second screens" - audience real-time engagement with content through mobile and tablet devices. However, as an April 2014 survey from the Nielsen-funded Council for Research Excellence has suggested, only 16 percent of those surveyed said they had used social media while watching television, and less than half of those who did were conversing about the show they were watching. Entertainment and sports shows were more popular for social TV, and news as a category did not even register as an area of interest among those engaging in social TV. In terms of discovering new content, traditional broadcast promotions are far more important than social media channels, the report finds. ${ }^{68}$

Finally, there is the reality that not every type of story will be potentially viral. Some kinds of important stories have niche audiences; and they will only be produced by professional media organizations with serious reporting capacity.

"A Wall Street Journal article on Greek bonds or company results may not have the same potential to spread virally as a BuzzFeed-style list of 23 hipster cats, for example," Marshall notes, "but the news and information provided by the Journal is hugely important and highly sought after by a loyal community of readers.”

She notes that her outlet sees high volumes of traffic on social platforms such as Twitter 643,000 tweets, based on 7,400 articles shared in March 2014 - but raw numbers are not the only way of measuring quality engagement. "We can digest the quick-hit, fast-food, sugar rush of fun content that is great to consume and share," Marshall says. "And much of that is entertainment content rather than news. Then there is the more considered, nourishing news and information that may not find its way into millions of Facebook feeds but will still be read by millions or thousands of people. And while it may not all entertain, it is of great importance.” ${ }^{69}$

This basic reality means that a broadcast, or one-to-many, dynamic will likely remain in place across many domains of news and information.

\section{Pathways to Sharing}

Even as news organizations move toward greater audience engagement and openness at a policy level, the core psychology behind audience behavior around content must be considered. Media outlets' willingness to do this (along with keeping content open and accessible) will determine the degree of news audience agenda-setting. The early research suggests that highly emotional content that resonates with large numbers of people has the best chance to reach across social networks and be shared by large numbers of citizens. This does not necessarily mean "lighter" fare, but rather powerful stories that speak to deep hopes, fears and shared experiences.

BuzzFeed editor Ben Smith has said that "the standard for what someone will share is really high.” You can get people to click on "pretty much anything” based on a sensational, even misleading, headline, Smith says, which is part of the "great Web tradition of writing terrible, misleading headlines." However, he continues, "nobody ever shares something that they felt tricked into coming to. People share things that they are interested in, that they like, that they are proud to share. There's no real trick to it.,"70

In terms of understanding the psychology of content sharing, Sonya Song, a Mozilla Fellow hosted by the Boston Globe, notes that it is useful to consider the cognitive framework outlined in Nobel 
Laureate Daniel Kahneman's 2011 book Thinking, Fast and Slow. Kahneman states that we have two mental gears, so to speak: One involves rapid, highly intuitive comprehension, and the other a more engaged and rational analysis.

On social media platforms, Song says, we tend to favor and engage in fast thinking. Therefore, content accompanied by images, employs bold or all-caps type and uses simpler vocabulary makes us more likely to engage with and share it. That is not to say there is no place for more sophisticated content and approaches on social channels, however. "Don't hesitate to tell complicated stories, because they may engage people in slow thinking and result in receiving more feedback," Song concludes. Smart content - which provides a kind of reflected glow for sharers - can also help people "try to present themselves in an ideal way," she adds. As mentioned, highly emotional content — stories evoking awe, amusement, anger and anxiety alike — tends to be shared more often.

When Song analyzed the Globe's Facebook content in 2013, she found that arts stories and dry, factual stories, such as sports scores and business deals, were the least shared, while emotionproducing content across a wide variety of topics was shared more consistently. ${ }^{71}$

There appears to be a political element in this, as well. Brian E. Weeks and R. Lance Holbert of Ohio State University have found that the relationship between getting news through social sites and posting news through social media channels is stronger for political partisans than nonpartisans. ${ }^{72}$

In recent research, Amy Schmitz Weiss of San Diego State University, a former journalist, has been looking at related questions, particularly the process by which digital activities bring about different states of mind that allow for pleasure, curiosity and learning. She is exploring how the idea of "flow" - a social-science concept relating to a timeless state of clear-minded focus and engagement with a fulfilling task - might help us interpret why people spend large amounts of time online doing things for their own sake.

"When one productively participates in, recommends or discusses online activities or information with other online-users, online enjoyment and engagement are heightened and, hence, the experience of flow is facilitated," Schmitz Weiss writes in a 2014 paper co-authored for the journal New Media \& Society. Even though people are frequently only loosely connected online, they are attracted to spaces where there are communities of interest and likeness. As people feel "social capital affinity" - the collective bridges we build with loose networks and communities they become more likely to enter a state of flow online. Shoppers, for example, might form affinities as they participate collectively in reviewing products and searching for bargains. ${ }^{73}$

Schmitz Weiss says that there are a wide number of variables that factor into an individual's decision to share news content: both a person's own mental state and state in life at the time, as well as their sense of the community with which they might communicate. Because so many variables are involved, any social media audience will remain a "moving target," she says:

If you get settled and comfortable with a specific audience, your strategy will also become too comfortable and stale, which can equate to a long-term loss of audience. Striving for the audience to be aware and informed about your content and in turn reading it as well as sharing it with others should be the goal, not the demographic of who you are trying to reach. Content remains king. ${ }^{74}$ 
Talia Stroud, who heads the Engaging News Project at the University of Texas, agrees, noting that the testing of content will be crucial, given the constantly shifting nature of the audience. "We are only beginning to understand why people share news content," she says. "It seems likely that what makes content more or less shareable differs by topic. Some topics may require a compelling visual to increase sharing, others a catchy headline. I also suspect that what 'works' changes over time as people grow tired of a formula." ${ }^{75}$

In sum, the news media industry can play a significant role in its own democratization - and many outlets are moving toward such a future - but the extent to which this will become a reality soon is unclear.

\section{PART II: NETWORK PATTERNS AND INFLUENCE DYNAMICS}

\section{Offline and Online Networks: How Different?}

Digital networks magnify speed and scope, but the evidence we have so far does not suggest that the offline and online worlds are radically distinctive in terms of human behavior, or provide an altogether different set of dynamics and pathways around news and information.

James Fowler, a social scientist and network researcher at the University of California, San Diego, has delved deeply into how phenomena such as obesity and smoking spread through offline social networks. ${ }^{76} \mathrm{He}$ and Nicholas A. Christakis, a Yale physician and social network researcher, have looked at data on more than 12,000 individuals over 32 years from the Framingham Heart Study. This analysis - as well as peer-reviewed studies of other large datasets - has given them unique insights into social networks and the "rippling effects" of networked human behavior, and it has suggested a basic truth about offline social networks: Ties among individuals can facilitate strong behavioral changes up to three degrees of separation - what they call the "three degrees of influence" rule. ${ }^{77}$

Their work is not without controversy and critique. ${ }^{78}$ It is hard to say precisely how much people in social networks truly influence one another, versus how much we just are attracted to people like us, which on the surface looks like influence. Nevertheless, Fowler and Christakis have been on a quest to find "natural" laws about human social networks. Some of these insights caught the public's attention when the researchers published Connected: The Surprising Power of Our Social Networks and How They Shape Our Lives in $2009 .{ }^{79}$ In a 2012 paper co-authored for Nature, they even looked at the network structures of hunter-gatherer societies and found their social ties were almost identical to those of modernized societies. Fowler notes that prior to the digital age, people have always had several degrees of connections with strangers through human communities - putting our "natural," pre-digital influence networks in the several hundreds of people. ${ }^{80}$

The median number of friends on Facebook is about 200 and the average roughly 340; many of these, of course, are friends-of-friends, people we have met only incidentally and casually. ${ }^{81}$ In and of itself this does not represent an order-of-magnitude change. Other data suggest a mixed picture in terms of evolutionary, or revolutionary, change. A half-century ago, Stanley Milgram famously performed what's now called the "six degrees of separation" postcards experiment. He 
sent notes through the mail to people in Nebraska asking them to forward the message along to someone who might know a particular person in the Boston suburbs. Milgram found that there were between 4.4 and 5.7 intermediaries on average between the original, randomly chosen recipient of a postcard and the intended endpoint recipient. (It is always likely there are shorter pathways that were missed.) In the early 2000s, Duncan Watts, then at Columbia University, along with co-authors Peter Sheridan Dodds and Roby Muhamad, reconfirmed the "six degrees" thesis using email chains, estimating there were between five and seven steps between email users across a sample of 13 countries. ${ }^{82}$ A 2012 study of Facebook, which is not a representative sample of the national or global population and skews toward a higher socioeconomic group, found that there are about four degrees of separation on that network platform. ${ }^{83}$

In one of the most important studies to look at how online information can affect offline behavior, Fowler and a team of researchers analyzed Facebook's giant experiment on voting day in November 2010, involving more than 60 million people. Facebook displayed "Go Vote” messages and allowed people to signal their behavior to friends by clicking "I Voted." The researchers ultimately found that (a) Online messages through networks can indeed change offline behavior, and the study estimates that some 340,000 additional votes were cast because of the experiment; and (b) people respond primarily to the messages of friends with whom they have a strong bond in the "real" world, and the influence of close friends was about four times greater. ${ }^{84}$

The empirical evidence reveals a tighter relationship between offline and online worlds than many believe, Fowler says: "Everything that we have done so far has suggested that the changes that happen online are changes that could have happened in real life. The online world just facilitates those changes." 85

It is true that social media allow a more efficient method of going beyond our immediate circle, with commercial, political and social implications. In terms of truly enlarging our "real" social networks, though, the evidence for social media is mixed. Evidence from the General Social Survey, which has been tracking societal change for more than 40 years now, does not suggest a general increase in capacity of friendships in the United States since the advent of social media. ${ }^{86}$ There is little evidence that we all now have, say, twice the number very close friends that we had before. Technology primarily seems to be bringing us into contact with more strangers. Having a close personal relationship, however, remains the key condition for information to influence real behavior - or least makes influence much more likely.

\section{The Strength of Strong Ties}

At the edge of researchers' understanding of networks is an important but unsettled debate about how the links between people are changing. Ultimately, the answers in this area will be consequential for the future of news and information.

Even if strong ties are necessary for real behavioral change, new evidence also shows that the spread of emotions, such as status updates to friends saying you are feeling happy, can pass through weak ties on social platforms such as Facebook and move to friends only weakly connected in other cities and geographically remote places. ${ }^{87}$ In a 2014 paper, researchers Moira Burke of Facebook and Robert Kraut of Carnegie Mellon combine social network data with longitudinal surveys of some 3,700 Facebook users. They conclude that direct messages, comments and posts - as well as passive consumption of content - are all associated with people 
feeling increased "closeness" with ties on the network. They contend that, even when you account for communication through other channels - phone, email, etc. - "Facebook adds something over these channels." The relative effect is actually closer for non-family and weaker ties, Burke and Kraut contend. ${ }^{88}$

All of these patterns feed into a long-running debate about precisely which kinds of human connections, or ties, do what and how. If one traces this social networks debate back to its origin point, a clear touchstone emerges: Mark Granovetter's 1973 American Journal of Sociology paper “The Strength of Weak Ties," which has been cited in the academic literature more than 27,000 times in subsequent decades and continues to be central to the debate. In the paper, Granovetter looks at case studies of Boston communities that faced urban renewal challenges, requiring communities to organize and mobilize to preserve their existing configuration and way of life. He theorizes that communities with more weak ties were actually stronger and had more capacity for collective action. This is because weak ties provide "bridges" between strong friend groups, or "cliques." Mobilizations only spread when cliques can begin to move in the same direction, requiring coordinating links.

Ultimately, Granovetter argues, special kinds of weak ties allow us to gain access to information we would not ordinarily encounter. By contrast, our good friends, our strong ties, tend to circulate news and information we already know. Not so with "bridging” weak ties - friends of friends, and those several links away - who may indeed offer us vital new information and access points. $^{89}$

Granovetter, now at Stanford, has found that job leads, for example, are frequently acquired through bridging weak ties. He is skeptical that newer social jobs platforms such as LinkedIn are making a dramatic difference in this respect, as they artificially attempt to create more bridging weak ties for those in the network. "What I would call the 'real' weak ties are probably more powerful than the ones that are contrived," Granovetter has said, acknowledging that there has not been satisfactory research on that question. ${ }^{90}$

Even if the advent of social media has not significantly changed the qualities of our weak ties, it is an open question whether or not Granovetter's observations about strong ties still hold. Do our strong ties truly bind us into a narrow world of information - constituting a kind of "closure" within small, likeminded networks?

Forty years ago, Granovetter posited that strong ties are not bridge ties, as it is almost compulsory that our good friends know one another; the idea that our two good friends would not know one another is a "forbidden triad," he says, putting it in technical network analysis language. It is a phenomenon, in any case, that is "unlikely" to occur, though Granovetter acknowledges that to say it is "forbidden" is probably exaggerating the case. But his upshot is clear: "Intuitively speaking, this means that whatever is to be diffused can reach a large number of people ... and traverse greater social distance, when passed through weak ties rather than strong."

Jump to the present and the era of Facebook, and the company's own data scientists are observing patterns that validate some of these original, offline hypotheses. In 2012 they analyzed a giant dataset relating to a field experiment in which Facebook randomized how some 253 million users received information signals from friends. Some could see that their friends shared something, while others could not. In a conference paper, researchers Eytan Bakshy, Itamar Rosenn and Cameron Marlow of Facebook and Lada Adamic of the University of Michigan explained that 
users are "more likely to have the same information sources as their close friends, and that simultaneously, these close friends are more likely to influence subjects." 92 (Another paper from the Facebook team, "Social Influence in Social Advertising," presents similar findings with respect to the power of strong ties. ${ }^{93}$ ) Granovetter's claims about weak-tie advantages seem to be borne out: Facebook's data team finds that, although strong ties are more influential in terms of moving information across networks, it is the "more abundant weak ties who are responsible for the propagation of novel information." 94

Some technology thinkers do not think the original claims over strong ties are still valid. In Rewire: Digital Cosmopolitans in the Age of Connection (2013), Ethan Zuckerman of the MIT Center for Civic Media asserts that the online world fundamentally changes social networks and our ways of conceiving of social ties. He writes that Granovetter's assumptions "may have been true in 1973 when he wrote the paper, but they are more questionable today," because geography is less important, and people sometimes go online to connect with others over shared interests. Zuckerman writes: "In an age of digitally mediated friendships, it's quite possible — and likely quite common — for strong ties to be bridge ties." 95

Empirical analysis suggests that this may indeed be true. "It is commonly the case in people's offline social networks that a friend of a friend is your friend, too," researchers at the Pew Research Internet Project found in a study of the networks of some 270 social media users. "But on Facebook this is the exception, not the rule.... The average Facebook user in our sample had a friends list that is sparsely connected." 96

For his part, Granovetter remains unconvinced that these strong/weak-tie relationship dynamics are changing dramatically in the digital age:

I'm not sure why strong ties would serve this function in the digital world any more than in the "real" world. There has been a lot of research on large datasets, mostly cell phone calls rather than social media sites to be sure, and in that research, weak ties continue to play a special role in bridging.... In fact I would suspect that given the reduced cost of maintaining weak ties that results from the virtual world, their role as bridges might even be enhanced. That is my speculation, anyway. ${ }^{97}$

Answers in this debate matter greatly. If we can imagine our strong ties now bridging across networks, we can imagine a world in which behavior-changing information can increasingly spread quickly across disparate networks. This may happen especially as social network platforms build functionality - images, video, virtual reality, etc. - that allow online interactions to resemble offline ones.

A little-known fact about Granovetter's landmark paper is that it was roundly rejected in its initial form. He was publishing it in a context and milieu where scholars and commentators were criticizing the proliferation of weak ties in society. Urbanization, modernization and advanced capitalism were destroying the organic connections of traditional communities, leading to "alienation" and a host of related societal ills. But Granovetter was going against the intellectual grain - his original title was "Alienation Reconsidered: The Strength of Weak Ties." The "alienation" scholars rejected the argument, Granovetter says, because they felt he was trying to revive the reputation of casual and incidental relationships. ${ }^{98}$ 
Four decades later, we now encounter an entirely different problem, this time around strong ties: It is the narrowness of our social groups, their partisan and socioeconomic cast, that have come under scrutiny. The problem is what social scientists call "homophily," the tendency for likeminded persons to cluster together. There are great worries about "cyberbalkanization" and "filter bubbles," as Eli Pariser, Upworthy's founder, has put it, and a tendency for the digital world to reinforce extreme beliefs. In this context, the hope is that strong ties themselves might begin to function differently because of digital networks.

In any case, it is clear that the numerical expansion of our weak tie relationships is broadening the information many citizens encounter. But while the nature of strong ties may be changing incrementally, there is not strong empirical evidence yet that a wholesale shift is taking place.

\section{Superconnectors and Network Science}

The superficial perception has been that certain "superconnectors" - powerful individuals — are the keys to unlocking networks and spreading messages, but recent research has cast some doubt on this.

In human social networks offline, people frequently have only a few good friends, but there will be a few people with many friends, representing a phenomenon that is well beyond what a normal distribution would like. These special persons' networks are "hubby" - with many spokes extending out to other people from the central hub. Likewise, on social networks such as Facebook, research has shown that there are certain "power users" - about one in every four or five people - who share and post much more frequently than other users.

A 2012 report from the Pew Internet and American Life Project notes that, while the average Facebook user can hypothetically reach about 157,000 at two degrees of separation (friends-offriends) and the median user can reach about 31,000, the most influential power users can reach nearly 8 million other Facebook users through friends-of-friends. ${ }^{99}$ The same sorts of distributions in relative broadcast power are also reflected on other social networking sites such as Twitter. A 2011 study from Cornell and Yahoo! Research found that, among a dataset of 42 million Twitter users with 1.5 billion corresponding ties between them, just 20,000 "elite users" generated half of all the links that were consumed. ${ }^{100}$ Other research suggests that the vast majority of people on social media are relatively passive consumers of information, and do not forward content to the network frequently. ${ }^{101}$

The conventional wisdom from marketing science is that these types of power users and superconnetors matter a great deal. In his 2002 book The Tipping Point, Malcolm Gladwell has popularized these ideas with his "law of the few." Paul Revere succeeded in creating a word-ofmouth "epidemic" at the start of the American Revolution, Gladwell writes, because he was a special kind of person. In fact, fellow revolutionary William Dawes did the same kind of ride, with the same message, at the same time. But he failed to reach a wide audience. So why did Revere succeed? "The answer is that the success of any kind of social epidemic is heavily dependent on the involvement of people with a particular and rare set of social gifts," Gladwell writes. ${ }^{102}$

Taking a step back, what exactly is a "connector" from a network science perspective? For decades, social scientists have theorized about networks based on limited evidence. Now, digital trace data actually allow us to test these theories with huge samples. 
Over the past decade or so, a huge amount of work across disciplinary lines has gone into analyzing network effects, from chemistry and physics to the social sciences. Researchers have built up a highly sophisticated set of models and technologies to begin measuring network dynamics and influence. We can now begin to answer questions that, prior to the digital age, were largely matters of speculation or were areas of study informed only by small data samples.

In academic theory, connection points are known as "nodes," and the links between those nodes are "edges." At the very basic level, statistically analyzing any graph of nodes might reveal that some nodes are more central. Some have more connections; some are between more nodes and have the shortest paths to others; some nodes have more connections from other highlyconnected nodes. This form of network science, a quantitative shift toward the way we think about the world, is a defining feature of twenty-first century life, commerce and mass communications: Everything from Google's search algorithm, PageRank, to the recommendation engines of Amazon and Netflix to the data-mining techniques of intelligence agencies like the National Security Agency are powered by network science that finely slices and deploys this idea of centrality. ${ }^{103}$

One important formula that now very much organizes what we know and what is relevant - the defining way of charting influence - is a funny-sounding bit of network analysis statistics called "eigenvector centrality," which Google founders Larry Page and Sergey Brin famously proposed as part of the basis for their search algorithm in a 1998 paper they wrote as computer science graduate students at Stanford. ${ }^{104}$

Web pages that have more influential pages linking to them are given special status. Influence begets influence. A blogger with many influential friends hyperlinking and pointing to her, in other words, is considered to be exceptionally influential - and to have a high degree of eigenvector centrality. The principles and formulas of centrality, and the network theory around them, are a game-changing way of organizing some huge portion of the way we think about society. They are informing academic, commercial and government work across the world. In an era of big data, these are the models and tools that allow us to understand information and social networks in a more precise way.

\section{Anxiety of Digital Influence}

The very notion of influence on the Web and within digital social networks is uncertain, and because of the ability to manipulate data and appearances, establishing precise measurements will be difficult.

If a message is to be absorbed and passed along by many people, it is presumably helpful to have someone central to a vast network and powerful within it. This "influencer" in a sense holds the keys to having improved "reach." A powerful news pundit; a world leader; a prominent activist: These are frequently considered the crucial ingredients to achieving "viral lift."

Brian Solis of Altimeter Group, a brand marketing expert and new media analyst, has defined influence as the "ability to cause effect, change behavior, and drive measurable outcomes online." The key to unlocking influence, he has written, is social capital, which is "borrowed" from influential persons by brands to help reach other consumers. This transactional dance must be tailored to the particular cause at hand. In some campaigns, marketers might want to use more 
"popular" influentials - those with wide reach, like celebrities — while in others brands might do well to go with lower-profile but more authoritative connectors, such as experts. ${ }^{105}$

There are key contextual aspects of all this, such as timing and whether enough people may be paying attention. It also depends on how "costly" an action might be: Retweeting a message, for example, as opposed to actually clicking through and buying a product. The ultimate goal of pushing and diffusing a digital message may vary widely, of course. The world of e-commerce and online marketing has constructed elaborate models and algorithms for measuring influence and strategizing about viral messaging. Entrepreneurs have even set up online markets, such as Empire Avenue, where social reputation and capital can be traded. "We want you to be the one realizing your own value," Empire Avenue states on its site. "You are not a commodity, you are not the product, you are instead the person who should benefit from your knowledge, your reputation and your networks." 106

Companies such as Klout and PeerIndex and other influence software vendors have begun "scoring" and quantifying individuals across the Net, creating a new kind of social measure and currency. There are many other such tools and platforms: Kred; PROskore; TwitterGrader; TweetLevel; TweetReach; PeerPerks. The list goes on. ${ }^{107}$

It is an imperfect science, as many in the marketing world acknowledge. Nevertheless, as companies establish and target "influencers" across the social web, many people now are showered with gifts - movie screenings, hotel and travel deals, T-shirts, a free 20-piece Chicken McNuggets, whatever item might earn a modicum of reciprocal gratitude. The goal is to get influential people to talk about these products in social media space. The idea of harnessing fans — the people formerly known as the "audience" - to become co-conspirators in marketing campaigns is now everywhere. ${ }^{108}$

Studies in this area continue to show the uneven relationship between those with apparent mass followings and their ability to influence networks. A 2011 study by researchers Daniel M. Romero of Cornell, Wojciech Galuba of EPFL in Switzerland, and Sitaram Asur and Bernardo A.

Huberman of HP Labs examined a dataset of 2.5 million Twitter users and concluded that the "correlation between popularity and influence is quite weak, with the most influential users not necessarily being the ones with the highest popularity." 109

At a more general level, some researchers are deeply skeptical of these influence analysis engines. David Karpf, of George Washington University, has proposed a "rule of online data," where there is "an inverse relationship between the reliability of an online metric of influence and its financial or political value. Any metric of digital influence that becomes financially valuable, or is used to determine newsworthiness, will become increasingly unreliable over time.”110

As marketing expert Solis notes, this is indeed tricky terrain. In his 2012 "how-to" guide for businesses seeking “digital influence,” he quotes a very skeptical Microsoft Research/Harvardaffiliated researcher, danah boyd:

Social influence conforms to the Heisenberg uncertainty principle. The more precisely you try to measure one's influence, the more you muck up the entire system of influence. Klout and PeerIndex and similar services function through game mechanics. People who buy into the game are willing to manipulate their social media practices to get high status in these systems. But as they play the game - and as the companies 
respond to their gaming - those who are uninterested in the game end up getting written out of it. It evolves to be centered on the players. ${ }^{111}$

This "gaming" of the online influence economy has become big global business, and it does not bode well for the ability of individual citizens to exert organic influence within wider networks. As Nick Bilton of the New York Times has noted, there is a massive industry based on creating "bots," or fake Internet profiles, in order to generate attention for products and content. Web traffic numbers and approving comments thus surge. "These imaginary citizens of the Internet have surprising power," Bilton writes, "making celebrities, wannabe celebrities and companies seem more popular than they really are, swaying public opinion about culture and products and, in some instances, influencing political agendas." ${ }^{112}$

Between the rise of bots and the competitive race for billions in e-commerce, the game of influence is certain to remain contested space, casting doubt on the ability of organic, "bottom up" information and news content to grab attention on any consistent basis. Because "winning" this game takes significant capital, it is also likely that a relatively small number of gatekeepers will continually succeed in each new phase, as new influence metrics emerge, at the expense of other competitors with fewer resources. ${ }^{113}$

\section{No "Law of the Few"?}

Even if one devises a strategy to garner attention for certain content and to make it go viral across networks, there is evidence that the Internet is too fickle and random a space to execute the strategy with any certainty. There are instances of lone customers fighting back against airlines and government officials and succeeding, but getting a threshold level of attention is not the norm.

In his 2012 book Everything Is Obvious: How Common Sense Fails Us, Duncan Watts devotes an entire chapter, titled "Special People," to debunking the Gladwellian "law of the few." Watts demonstrates that the structure of a given network - people's receptivity to messages, and the degree to which they are paying attention - matters much more than individual influencers and their attributes. The analogy he employs is that of a forest fire: Only under certain conditions wind, dryness, etc. - will a spark become a roaring inferno. So too with "social epidemics." The key to exerting influence is having a "critical mass" of "easily influenced people who influence other easy-to-influence people.”

In 2009, Watts conducted a marketing experiment along with then-Yahoo! Research colleagues Jake Hofman and Winter Mason, and Eytan Bakshy, then a graduate student and now a leading Facebook data scientist. For their experiment, they plugged massive amounts of real Twitter data into computer simulations, and the results called into question the conventional wisdom about influential people. Watts recounts in his book:

What we found was surprising even to us: Even though the Kim Kardashians of the world were indeed more influential than average, they were so much more expensive that they did not provide the best value for the money. Rather, it was what we called ordinary influencers, meaning individuals who exhibit average or even less-thanaverage influence, who often proved to be the most cost-effective means to disseminate information. ${ }^{114}$ 
This is not to suggest that influence does not matter, and that some people do not carry outsize influence because of their stature and the power of their broadcast platform. For example, economists at the University of Maryland have estimated that Oprah Winfrey's endorsement of Barack Obama in the 2008 Democratic primary elections likely resulted in his getting one million extra votes. ${ }^{115}$ But the research suggests influence is frequently a more subtle, and less predictable, quantity than we often realize, and a careful cost-benefit analysis makes certain kinds of beliefs in, and bets on, the power of influence look unwise.

\section{New Orgs and Influence Targeting}

Some news media outlets have kept a careful eye on these debates over influentials and the importance of individuals to networks. No doubt, individual reporters and columnists, as well as social media managers, make sure that influential bloggers know about their new stories. But there are mixed views about what the future holds in terms of systematic efforts to reach influentials.

Sarah Marshall of the Wall Street Journal says she is somewhat skeptical of too calculated an approach. "I think you can over-strategize about reaching influential people within a community," she notes. "A great piece that is excellently sourced, thoroughly researched, wellwritten and clearly headlined will travel and find a wide reach. The fact that some readers are particularly influential and can accelerate the sharing is of course helpful, but treating all followers or members of a community as equal is preferable and will pay off in the long run."116

Even the most advanced digital organizations are still in the early stages. "So far, socially, we've focused mostly on broad audiences," NPR's Cooper says. "They've been the best bang for the buck. We've pushed to make our existing Web and radio audiences aware of what we're doing on social, and we've worked hard to create a distributed footprint that engages new audiences en masse.”

Yet new tools might open new possibilities for news organizations. "[W]e haven’t dismissed reaching new influencers," Cooper continues. "Until very recently, that kind of engagement has been difficult and expensive to scale, especially for a non-profit news organization like ourselves. But as social platforms evolve their APIs and liberate more real-time metadata, we're beginning to see opportunities. We're actually building an analytics dashboard for the newsroom right now, and it will tell us about social influencers on a story-by-story basis. It would be premature to say how we'll use that information. But we'll get the data in the door, find the trends and determine how it can help us." ${ }^{117}$

\section{Virality Debates: From Lab Research to BuzzFeed}

Viral events are a central part of the digital age - and these can make a difference during certain kinds of protests and instances of injustice - but it appears they are infrequent. Thus, they may not be a reliable feature that ensures greater democracy in terms of exposing "bottom up" news and information to large numbers of people and mobilizing action.

"One of the reasons that we are so interested in trying to figure out what makes something go viral is because it's so rare," said UCSD's Fowler. "I think the general critique that we have been 
studying this question by studying the successes, rather than studying both the successes and the failures, is correct." 118

Viral phenomena are potentially important from a democratic perspective because they can generate a "self-organized interest network" outside the control of traditional structures, the University of Washington's Nahon and her Going Viral co-author Jeff Hemsley argue. Viral events and content can perform bottom-up agenda-setting of a certain kind that cannot necessarily be controlled by powerful actors.

Perhaps the largest study to date on viral networks and structure comes from the Microsoft Research team - Sharad Goel, Jake Hofman and Watts - as well as Stanford's Ashton Anderson. In a 2013 research project they analyzed one billion links shared on Twitter in the categories of news, images, videos and petitions. It turns out that about one in every 3,000 links triggered a "large event," or a sharing pattern that reached 100 persons or more. However, truly viral events, defined by many multiple generations of sharing and a reach of several thousand adoptions at least, occurred on the order of about one in a million links shared. ${ }^{119}$

“These are very, very rare events," Goel, the lead author, says. “Almost always people are getting information directly from popular sources and they don't pass it along." He says the practical takeaway from these network science findings for social media managers of all kinds might be to focus on their "immediate" network:

So if I have somebody who I think is going to read my story, maybe they can persuade their friends to read the story. But their friends are probably not going to be able to persuade their friends. Having your mental model be 'All I care about is that one-degree neighborhood' simplifies one's view of the world, as opposed to just trying to think of these long chains.... If you know your demographic, and maybe you have some insight into that one-degree neighborhood of that demographic, that probably gets you a lot of the way there. ${ }^{120}$

Not all Internet thinkers agree precisely on this point, and the science of virality remains in its infancy. In fact, NYU's Clay Shirky argues that we may be thinking about virality in the wrong way. Measuring it might require much longer stretches of time and detecting pathways that have yet to be fully captured. ${ }^{121}$ Shirky notes:

I'd say, on the contrary, virality happens all the time. It's just easy to miss if you have a hit-driven/synchronized audience mentality. Everyone got how viral "Gangnam Style" was, but if you go to any 17-year-old and give them a list of a dozen or so recent viral phenomena - from Scumbag Steve to "Bae caught me slippin” to Dogecoin - most will recognize half the elements on the list. And many will recognize all of them, despite those things never having made the evening news. ${ }^{122}$

Watts might counter that the way most people encounter "viral content" like the popular "Gangnam Style" video, by South Korean musician Psy, is still by reading about it on major news sites and encountering it through large broadcast media. Anything that is big enough for you to hear about is likely not truly viral, Watts argues. The only counter-examples might be pornography or hate speech - things the mainstream news media will not touch. 
Shirky does agree that the "viral" frame often skews understanding of our new media environment:

The problem with the way people in traditional media organizations view viral content is that it is supposed to do the job of amassing large, stable audiences - the effect they are most missing from the old days - when a moment's reflection would show them why it can't: Attention is an arms race. If there are more people who can not just produce content but distribute it (and there are, by 10,000 times) then breakthrough virality will be rare and rapidly decaying, while 99 percent of virality is just the new background, ubiquitous but not unusual. ${ }^{123}$

Some of the debate over "viral" is a game of differing definitions. The Facebook data science team, in partnership with Stanford and Cornell researchers, is producing research that is getting closer to identifying the key technical characteristics of viral content. ${ }^{124}$ Nahon and Hemsley synthesize much of the academic work to date and reasonably define virality as:

[A] social information flow process where many people simultaneously forward a specific information item, over a short period of time, within their social networks, and where the message spreads beyond their own social networks to different, often distant networks, resulting in a sharp acceleration in the number of people who are exposed to the message. ${ }^{125}$

The essential component of virality is that the content is significantly spread peer-to-peer; otherwise, it is no different than any big media event of previous eras in terms of the pattern of influence.

\section{Viral and News: A Lesson}

A fascinating final thread in all of this connects back to the news business - and its leading edge. In 2007, Watts co-authored an article for Harvard Business Review on viral marketing with Jonah Peretti, who as the founder of BuzzFeed has since become one of the most important figures in the news business. ${ }^{126}$ A roiling amalgam of superficial entertainment news, quizzes and "listicles," as well as high-quality reporting, BuzzFeed sees massive Web traffic, much of it from social networks and peer-to-peer sharing. Both Watts and Peretti agree that we are thinking about virality all wrong. The key is what they call "big seed" or "sub-viral" marketing - the technique of doing a large broadcast with a kind of viral "kick" on the end of it. This remains the secret of BuzzFeed.

"As we pointed out in that article, things don't have to go viral in the traditional, mathematical sense of the reproductive rate exceeding 1, and showing exponential growth," Watts says. Even if your reproductive rate is half, 0.5 , which looks like a poor rate of sharing through a network, you can double the number of people you end up reaching. This matters if your initial audience is large. "We realized this when we were looking at a bunch of campaigns that Jonah had run, long before he started BuzzFeed," Watts continues, "And we were trying to find evidence of viral spreading. We kept being disappointed, as we were seeing numbers of reproduction less than 1.”

Tens of millions of people come to BuzzFeed's home site; many then post that article on Facebook. Other co-publishing sites help with this, too. Every story is potentially exposed to millions of people, and Twitter and Facebook shares are the kind of "halo" around that initial seed. BuzzFeed 
is an industry leader in optimizing its content for social sharing, with attractive headlines, clever and hip story framings and images. It constantly experiments with story form through A/B testing to see how audiences respond. But it gets surprised all the time, as content that looks like a sure bet underperforms, or vice versa.

The overarching takeaway from this mix of computational social science and news experimentation is that small differences in the reproduction rate of information content can be the difference between a 50 percent gain in audience and a 100 percent gain in audience. So figuring out the right content and form for the initial "big seed" media broadcast is crucial in terms of the aggregate audience reached. "The point is the absolute number of new recruits you get," Watts says. ${ }^{127}$

\section{Conclusion: The Future of Influence, Networks and News}

Establishing exactly how a fact or story goes from being a small nugget, known by only a few, to a giant, society-wide phenomenon that commands attention and even mobilizes action is difficult. Did it travel by word of mouth, or peer-to-peer, for the majority of its journey? Or did a producer in a mainstream media outlet snatch it from obscurity and broadcast it to millions? These macro questions have seen little sustained research attention to date. The era of "big data" offers new possibilities.

Two recent research case studies have shed some light on these issues. A team at Harvard that included Yochai Benkler studied how people mobilized to defeat bills in Congress, "SOPA" and "PIPA," that would have provided new legal avenues for pursuing online piracy. The findings show that less-known persons from many corners were instrumental in generating mass attention. ${ }^{128}$

According to researchers Benkler, Hal Roberts, Robert Faris, Alicia Solow-Niederman and Bruce Etling:

A major node like Wikipedia may be secondary, while an otherwise minor node, such as the blog of a law professor commenting on an amendment or a technical paper on DNS security, may be more important. The dynamic nature of attention in controversies over time means that prior claims regarding a re-concentration of the ability to shape discourse miss vital fluctuations in influence and visibility.

Because attention fluctuates as topics unfold, they argue, it appears there can be "greater diversity of opportunity to participate in setting and changing the agenda early in the debate compared to the prevailing understanding of the power law structure of attention in digital media.”

By contrast, a 2014 study using similar research and data tools to analyze the story of Trayvon Martin, a young African-American who was shot and killed by a Neighborhood Watch volunteer, George Zimmerman, found different dynamics. "Our analysis finds that gatekeeping power is still deeply rooted in broadcast media," write MIT Center for Civic Media researchers Erhardt Graeff, Matt Stempeck and Ethan Zuckerman. "Without the initial coverage on newswires and television, it is unclear that online communities would have known about the Trayvon Martin case and been able to mobilize around it.” Bottom-up activism mattered at crucial moments as the story unfolded, but so, overwhelmingly, did major television stations. ${ }^{129}$ 
Whether the information ecosystem will tip toward more gatekeepers or grassroots in terms of agenda-setting is a largely abstract question - perhaps the networked media world is now too big and diverse to expect a single answer, and it will vary from issue to issue, story to story. What is increasingly clear, however, is that a hybrid system has begun to evolve, one that can be at times just as unequal in terms of voice, power and attention, despite all of technology's promise.

The broadcast activated model, with media elites doing most of the agenda-setting, still dominates the way Americans access and engage with news. Taking social media engagement with news as a proxy, we might estimate that 90 percent or more of content is still received through a direct broadcast, one way or another. While bottom-up information surges and user-generated content have a strong role in the areas of entertainment and culture, the bulk of the civically important information still rests in the hands of a set of gatekeepers that has expanded in size, but nevertheless represents nothing like a radically democratic utopia of news and information. We have in large measure democratized the production of information, but we continue to see hyperconsolidation at the top level - delivery, or the "last mile" of reaching mass audiences, has not been democratized. ${ }^{130}$

Finally, it should also be noted that pending changes to the underlying policies governing the Web could be consequential, even decisive, in this regard. Altering the principle of net neutrality particularly any shift that requires media producers to pay Internet service providers to reach end users - could radically shift the balance back toward big media. It could make, as former FCC commissioner Michael Copps has said, "news and information a luxury good.”131

Still, these are "early days" in the history of the social web. Eric Newton, senior advisor to the president of the Knight Foundation - the nation's leading funder of pioneering digital news and civic projects, tools and ideas - says that analytical caution remains in order. "The digital age is young; we don't know how it will turn out," Newton warns. "Personal expression and democracy may flourish and the planet may solve its own problems.... Or maybe personal expression will explode but for some reason democracy will shrivel. Our future is being shaped every day by the countless decisions people make.”132 
Acknowledgements: My thanks to the following for help with various aspects of this paper: At the Shorenstein Center, Tom Patterson, Nancy Palmer, Alex Jones, Jeff Seglin, Leighton Kille, Janell Sims, Marion Just, Jim Fleming, Richard Parker, Matt Baum, Nicco Mele, Edie Holway and Paul Sagan. My gratitude, as well, to Josh Benton at Harvard's Nieman Journalism Lab, Deen Freelon at American University, Daniel Frohlich at NPR, Alex Remington at the Washington Post, Nicholas Lemann at Columbia University and Eric Newton at the Knight Foundation. I would also like to thank Carrie Wihbey for all of her help and support. 


\section{Endnotes}

1 Hindman, Matthew. The Myth of Digital Democracy. (Princeton, N.J.: Princeton University Press, 2008), 17.

2 Thrall, Trevor; Stecula, Dominik; Sweet, Diana. "May We Have Your Attention Please? Human-Rights NGOs and the Problem of Global Communication.” International Journal of Press/Politics, 2014. doi: 10.1177/1940161213519132. Available at: http://hij.sagepub.com/content/19/2/135.

3 Benkler, Yochai. The Wealth of Networks: How Social Production Transforms Markets and Freedom (Yale University Press, New Haven, Conn., 2006).

4 Nahon, Karine; et al. "Blogs: Spinning a Web of Virality,” Proceedings of the 2011 iConference. doi: 10.1145/1940761.1940809. Available at: http://dl.acm.org/citation.cfm?id=1940809.

5 Mitchell, Amy; Guskin, Emily. “Twitter News Consumers: Young, Mobile and Educated,” Pew Research Journalism Project, Nov. 4, 2013. Available at: http://www.journalism.org/2013/11/04/twitter-newsconsumers-young-mobile-and-educated/.

6 Saad, Lydia. “TV Is Americans’ Main Source of News,” Gallup Politics, July 8, 2013. Available at: http://www.gallup.com/poll/163412/americans-main-source-news.aspx.

7 American Press Institute. The Personal News Cycle: How Americans Choose to Get Their News, 2014. Available at: http://www.americanpressinstitute.org/publications/reports/survey-research/personal-newscycle/.

8 Flaxman, Seth; Goel, Sharad; Rao, Justin M. "Ideological Segregation and the Effects of Social Media on News Consumption,” 2013. Available at: http://papers.ssrn.com/sol3/papers.cfm?abstract id=2363701.

9 Pew Research Center. Social, Search \& Direct: Pathways to Digital News, 2014. Available at: http://www.journalism.org/files/2014/03/pathways to news topline.pdf.

${ }^{10}$ Kleis Nielsen, Rasmus; Schrøder, Kim Christian. "The Relative Importance of Social Media for Accessing, Finding, and Engaging with News,” Digital Journalism (2014). doi: 10.1080/21670811.2013.872420. Available at: http://www.tandfonline.com/doi/abs/10.1080/21670811.2013.872420.

11 Reuters Institute for the Study of Journalism. Reuters Institute Digital News Report (2013). Available at: https://reutersinstitute.politics.ox.ac.uk/fileadmin/documents/Publications/Working Papers/Digital News Report 2013.pdf.

12 American Press Institute, 2014.

13 Pew Research Center. Key Indicators in Media and News, 2014. Available at: http://www.journalism.org/files/2014/03/Key-Indicators-in-Media-and-News-2014.pdf

${ }^{14}$ New York Times, "Innovation," internal report, 2014. Available at: http://www.scribd.com/doc/224332847/NYT-Innovation-Report-2014.

${ }^{15}$ Seward, Zack. "The Home Page Is Dead and the Social Web Has Won - even at the New York Times," Quartz, May 15, 2014. Available at: http://qz.com/209950/the-homepage-is-dead-and-the-social-web-haswon-even-at-the-new-york-times/.

${ }^{16}$ New York Times, "Innovation."

17 Webster, James G.; Ksiazek, Thomas B. "The Dynamics of Audience Fragmentation: Public Attention in an Age of Digital Media.” Journal of Communication, 2012. doi:10.1111/j.1460-2466.2011.01616.x. Available at: http://onlinelibrary.wiley.com/doi/10.1111/j.1460-2466.2011.01616.x/abstract.

18 Nahon, Karine; et al. "Blogs: Spinning a Web of Virality."

19 O’Donovan, Caroline. “Q\&A: Clark Medal Winner Matthew Gentzkow Says the Internet Hasn’t Changed News as Much as We Think,” Nieman Journalism Lab, April 29, 2014. Available at: http://www.niemanlab.org/2014/04/qa-clark-medal-winner-matthew-gentzkow-says-the-internet-hasntchanged-news-as-much-as-we-think/. 
20 The Economist, “Guru: Herbert Simon,” March 20, 2009. Available at: http://www.economist.com/node/13350892.

${ }^{21}$ Talbot, Margaret. “Who Wants to Be a Legionnaire?” New York Times, June 25, 2000. Available at: http://www.nytimes.com/books/00/06/25/reviews/000625.25talbott.html.

22 Bennett, W. Lance; Manheim, Jarol B. “The One-Step Flow of Communication,” Annals of the American Academy of Political and Social Science, 2006. doi: 10.1177/0002716206292266. Available at: http://ann.sagepub.com/content/608/1/213.short.

${ }^{23}$ Author interview with Ducan Watts, April 20, 2014.

${ }^{24}$ Goel, Sharad; et al. "The Structural Virality of Online Diffusion,” Microsoft Research, 2013.

${ }^{25}$ Nahon, Karine; Hemsley, Jeff. Going Viral (Polity Press, Cambridge, U.K., 2013), pp. 41-55.

${ }^{26}$ Author interview via email with Clay Shirky, April 14, 2014. As of June 6, 2014, technologist Anil Dash had 498,000 followers on Twitter, while author and technologist Tim O'Reilly had 1.77 million.

${ }^{27}$ Freelon, Deen; Karpf, David. "Of Big Birds and Bayonets: Hybrid Twitter Interactivity in the 2012 Presidential Debates," unpublished working paper shared with author, February 26, 2014. This paper also benefitted from numerous conversations and email exchanges with both scholars in early 2014.

28 Tufekci, Zeynep. “'Not This One': Social Movements, the Attention Economy, and Microcelebrity Networked Activism.” American Behavioral Scientist, 2013. doi: 10.1177/0002764213479369. Available at: http://m.abs.sagepub.com/content/57/7/848.

${ }^{29}$ Lin, Yu-Ru, et al. "Rising Tides or Rising Stars?: Dynamics of Shared Attention on Twitter during Media Events," PLoS One, May 22, 2014. doi: 10.1371/journal.pone.0094093. Available at: http://www.plosone.org/article/info\%3Adoi\%2F10.1371\%2Fjournal.pone.0094093

${ }^{30}$ Max Knoblauch. "Internet Users Send 204 Million Emails Per Minute," Mashable, April 23, 2014. Available at: http://mashable.com/2014/04/23/data-online-every-minute/.

31 Castells, Manuel. Communication Power (Oxford, New York: Oxford University Press, 2009.)

32 Engaging News Project. Interactive Features in Online News, 2014. Available at: http://engagingnewsproject.org/news-site-analysis/.

33 Stroud, Natalie Jomini; Scacco, Joshua M.; Curry, Alexander L.. News Engagement Workshop Report, Engaging News Project, 2014. Available at: http://engagingnewsproject.org/wpcontent/uploads/2014/04/ENP Workshop Report.pdf.

${ }^{34}$ Huey, John; Nisenholtz, Martin; Sagan, Paul. "Riptide: What Really Happened to the News Business," Discussion Paper, Shorenstein Center on the Press, Politics and Public Policy, Harvard Kennedy School, 2013. Available at: http://shorensteincenter.org/2013/09/d81-riptide/.

35 Andreessen, Marc. "The Future of the News Business: A Monumental Twitter Stream All in One Place," Andreessen Horowitz. Available at: http://a16z.com/2014/02/25/future-of-news-business/.

${ }^{36}$ Pew Research Center's Project for Excellence in Journalism, “The State of the News Media,” 2012. Available at: http://stateofthemedia.org/2012/digital-news-gains-audience-but-loses-more-ground-in-chasefor-revenuel.

${ }^{37}$ Parse.ly, The Authority Report, 2014. Available at: http://marketingland.com/facebook-cuts-googles-leadtop-traffic-driver-online-news-sites-report-75578.

38 Facebook, "News Feed FYI: Showing More High Quality Content," Aug. 23, 2013. Available at: https://www.facebook.com/business/news/News-Feed-FYI-Showing-More-High-Quality-Content

39 Parse.ly, The Authority Report, 2014.

40 The Whip, 2014. The Biggest Twitter Publishers of March 2014. Available at: http://blog.newswhip.com/index.php/2014/04/biggest-twitter-publishers-march-2014.

41 Author interview via email with Sarah Marshall, April 13, 2014. 
42 Hermida, Alfred. “The Year We Get Smart about Social Media,” Nieman Journalism Lab, December 20, 2013. Available at: http://www.niemanlab.org/2013/12/the-year-we-get-smart-about-social-media/

43 Willnat, Lars; Weaver, David. "Journalists in the Digital Age: Key Findings,” (2014), Indiana University School of Journalism. Available at: http://news.indiana.edu/releases/iu/2014/05/2013-american-journalistkey-findings.pdf.

${ }^{44}$ Hermida, Alfred; Lewis, Seth C.; Zamith, Rodrigo. "Sourcing the Arab Spring: A Case Study of Andy Carvin's Sources on Twitter During the Tunisian and Egyptian Revolutions." Journal of Computer-Mediated Communication (2014). doi:10.1111/jcc4.12074. Available at: http://onlinelibrary.wiley.com/doi/10.1111/jcc4.12074/abstract;jsessionid=C5967ADC35AA99AAF480A5ADF 04CB086.f01t01.

${ }^{45}$ NPR Fact Sheet, November 2013, Available at: http://www.npr.org/about/press/NPR Fact Sheet.pdf. NPR's Daniel Frohlich notes in a May 19, 2014 email that updated Nielsen Audio numbers for fall 2013 put NPR's audience numbers at 27.3 million weekly listeners.

${ }^{46}$ NPR internal Web analytics data spreadsheet provided to author via email, March 26, 2014. A special thanks to NPR's Daniel Frohlich and Patrick Cooper.

${ }^{47}$ Pew Research Center. Social, Search \& Direct: Pathways to Digital News, 2014. Available at: http://www.journalism.org/files/2014/03/pathways to news topline.pdf.

${ }^{48}$ NPR internal data spreadsheet. Many thanks to Daniel Frohlich for confirming these percentages.

49 Author interview via email with Patrick Cooper, April 18, 2014.

50 Mitchell, Amy et al. “The State of the News Media 2013,” Pew Research Center’s Project for Excellence in Journalism, March 2013. Available at: http://stateofthemedia.org/2013/overview-5/.

51 The Whip, 2014.

${ }^{52}$ Boston Globe internal analytics data spreadsheet shared with author, April 3, 2014. A special thanks to the Globe's Joel Abrams.

53 Boston Globe, "Beta Boston,” May 19, 2011. Retrieved from: http://betaboston.tumblr.com/post/10139526149/archival-photos-of-the-globes-strangely.

54 Author interview with Joel Abrams at Boston Globe, March 27, 2014; email interview May 7, 2014.

55 Boston Globe internal analytics data.

${ }^{56}$ Author interview via email with Patrick Cooper.

${ }^{57}$ NPR internal data spreadsheet.

58 Ananny, Mike. "Networked Press Freedom and Social Media: Tracing Historical and Contemporary Forces in Press-Public Relations.” Journal of Computer-Mediated Communication, 2014. doi: 10.1111/jcc4.12076. Available at: http://onlinelibrary.wiley.com/doi/10.1111/jcc4.12076/abstract.

${ }^{59}$ Usher, Nikki. “Why Spreadable Doesn’t Equal Viral: A Conversation with Henry Jenkins,” Nieman Journalism Lab, November 23, 2010. Available at: http://www.niemanlab.org/2010/11/why-spreadabledoesnt-equal-viral-a-conversation-with-henry-jenkins/.

${ }^{60}$ Pew Research Center. “Social, Search \& Direct: Pathways to Digital News,” 2014.

${ }^{61}$ Pew Research Center. "The Role of News on Facebook,” 2013. Available at: http://www.journalism.org/2013/10/24/the-role-of-news-on-facebook/

62 Author interview via email with Clay Shirky.

${ }^{63}$ Haile, Tony. "What You Think You Know About the Web Is Wrong," Time magazine, March 9, 2014. Available at: http://time.com/12933/what-you-think-you-know-about-the-web-is-wrong/.

${ }^{64}$ Mitz, Daniel. “Three Interesting Things Attention Minutes Have Already Taught Us,” Upworthy Insider, February 13, 2014. Available at: http://blog.upworthy.com/post/76538569963/3-interesting-thingsattention-minutes-have-already. 
65 Salmon, Felix. "Viral Math,” Reuters, February 2, 2014. Available at: http://blogs.reuters.com/felixsalmon/2014/02/02/viral-math/.

${ }^{66}$ Huddack, Mike. Facebook article post, May 22, 2014. Available at: https://www.facebook.com/mhudack/posts/10152148792566194

${ }^{67}$ Mitz, Daniel.

${ }^{68}$ Council for Research Excellence, “Talking Social TV 2," April 10, 2014. Available at: http://www.researchexcellence.com/documents/misc/CRE Talking_Social TV_2 Clients Meeting_FINAL 04 092014.pdf.

69 Author interview via email with Sarah Marshall.

${ }^{70}$ Shorenstein Center on Media, Politics and Public Policy event archive, "Thoughts on the Media Future: N.Y. Times' David Carr, BuzzFeed's Ben Smith, MSNBC's Andrea Mitchell,” 2014. Available at: http://shorensteincenter.org/2014/02/thoughts-media-future-n-y-times-david-carr-buzzfeeds-ben-smithmsnbcs-andrea-mitchell/.

${ }^{71}$ Song, Sonya. "Sharing Fast and Slow: The Psychological Connection Between How We Think and How We Spread News on Social Media,"Nieman Journalism Lab, Nov. 15, 2013. Available at: http://www.niemanlab.org/2013/11/sharing-fast-and-slow-the-psychological-connection-between-how-wethink-and-how-we-spread-news-on-social-media/.

${ }^{72}$ Weeks, Brian E.; Holbert, R. Lance. "Predicting Dissemination of News Content in Social Media A Focus on Reception, Friending, and Partisanship.” Journalism \& Mass Communication Quarterly, 2013. doi: 10.1177/1077699013482906. Available at: http://jmq.sagepub.com/content/90/2/212.short.

73 Barker, Valerie; Dozier, David M.; Schmitz Weiss, Amy; Borden, Diane L. "Harnessing Peer Potency: Predicting Positive Outcomes from Social Capital Affinity and Online Engagement with Participatory Websites." New Media \& Society, 2014. doi: 10.1177/1461444814530291. Available at: http://nms.sagepub.com/content/early/2014/04/06/1461444814530291.abstract.

${ }^{74}$ Author interview with Amy Schmitz Weiss, March 11, 2014; interview via email, April 20, 2014.

75 Author interview via email with Talia Stroud, May 8, 2014.

${ }^{76}$ Author interview with James Fowler, March 7, 2014.

${ }^{77}$ Fowler, James H.; Christakis, Nicholas A. "Dynamic Spread of Happiness in a Large Social Network: Longitudinal Analysis of the Framingham Heart Study Social Network.” BMJ, September 2008. doi: http://dx.doi.org/10.1136/bmj.a2338. Available at: http://dash.harvard.edu/handle/1/3685822.

78 Shalizi, Cosma R.; Thomas, Andrew C. "Homophily and Contagion Are Generically Confounded in Observational Social Network Studies.” Sociological Methods \& Research, 2011. doi: 10.1177/004912411140482. Available at: $\underline{\text { http://smr.sagepub.com/content/40/2/211.short. }}$

${ }^{79}$ Christakis, Nicholas A.; Fowler, James H. Connected: The Surprising Power of Our Social Networks and How They Shape Our Lives (Back Bay Books, 2009).

${ }^{80}$ Apicella, Coren L.; Marlowe, Frank W.; Fowler, James H.; Christakis, Nicholas A. "Social Networks and Cooperation in Hunter-Gatherers.” Nature, 2012. doi: 0.1038/nature10736. Available at: http://www.nature.com/nature/journal/v481/n7382/full/nature10736.html.

81 Pew Research Center. “Six New Facts About Facebook,” 2014. Available at: http://www.pewresearch.org/fact-tank/2014/02/03/6-new-facts-about-facebook/.

82 Dodds, Peter Sheridan, Muhamad, Roby; Watts, Duncan J. "An Experimental Study of Search in Global Social Networks.” Science, 2003. doi: 10.1126/science.1081058. Available at: http://www.sciencemag.org/content/301/5634/827.abstract

83 Backstrom, Lars; et al. "Four Degrees of Separation." Proceedings of the third annual ACM Web Science conference, 2012. doi: 10.1145/2380718.2380723. Available at: http://dl.acm.org/citation.cfm?id=2380723. 
${ }^{84}$ Fowler, James H. et al. "A 61-Million-Person Experiment in Social Influence and Political Mobilization.” Nature, 2012. doi: 10.1038/nature11421. Available at: http://www.nature.com/nature/journal/v489/n7415/full/nature11421.html.

${ }^{85}$ Author interview with James Fowler.

${ }^{86}$ General Social Survey, Available at: http://www3.norc.org/gss+website/

${ }^{87}$ Kramer, Adam D.I., et al. "Experimental Evidence of Massive-scale Emotional Contagion through Social Networks," Proceedings of the National Academy of Sciences (PNAS), June 2014, doi:

10.1073/pnas.1320040111. Available at: http://www.pnas.org/content/early/2014/05/29/1320040111.abstract

${ }^{88}$ Burke, Moira, and Robert Kraut. "Growing Closer on Facebook: Changes in Tie Strength Through Social Network Site Use." Proceedings of the SIGCHI Conference on Human Factors in Computing Systems. ACM, 2014. Available at: https://www.facebook.com/notes/facebook-data-science/growing-closer-onfacebook/10152086044728859.

${ }^{89}$ Granovetter, Mark. "The Strength of Weak Ties,” American Journal of Sociology, 1973. Available at: http://www.jstor.org/stable/2776392.

${ }^{90}$ Mark Granovetter, “2013 Everett M. Rogers Award Colloquium,” October 1, 2013. Available at: https://www.youtube.com/watch?v=919VYXKn6sg.

${ }^{91}$ Granovetter, Mark. "The Strength of Weak Ties.”

92 Bakshy, Eytan; et al. "The Role of Social Networks in Information Diffusion.” Proceedings of the 21st International Conference on World Wide Web, 2012. Available at: http://dl.acm.org/citation.cfm?id=2187907

93 Bakshy, Eytan; et al. "Social Influence in Social Advertising: Evidence from Field Experiments," Proceedings of the 13th ACM Conference on Electronic Commerce, 2012. doi: 10.1145/2229012.2229027. Available at: http://arxiv.org/abs/1206.4327.

94 Bakshy, Eytan; et al. "The Role of Social Networks in Information Diffusion.”

${ }^{95}$ Zuckerman, Ethan. Digital Cosmopolitans in the Age of Connection (W.W. Norton \& Company, New York, 2013) pp. 177-180.

${ }_{96}$ Pew Research Internet Project, 2012. “Why Most Facebook Users Get More Than They Give.” Available at: http://www.pewinternet.org/2012/02/03/why-most-facebook-users-get-more-than-they-give/.

97 Author interview via email with Mark Granovetter, May 21, 2014.

98 Granovetter, Mark, Everett M. Rogers Award Colloquium, 2013.

99 Pew Internet and American Life Project. “Why Most Facebook Users Get More Than They Give,” 2012.

${ }^{100}$ Wu, Shaomei; Hofman, Jake M.; Mason, Winter A.; Watts, Duncan J. "Who Says What to Whom on Twitter.” Proceedings of the 20th International Conference on World Wide Web, 2011. Available at: https://iriss.stanford.edu/sites/all/files/dsi/Duncan\%20Study\%201.pdf.

${ }^{101}$ Romero, Daniel M. ; et al. "Influence and Passivity in Social Media," 2011 Available at: http://www.hpl.hp.com/research/scl/papers/influence/influence.pdf

102 Gladwell, Malcolm. The Tipping Point (Little Brown, 2000), Chapter 2. In 2013, Kiernan Healy, a Duke sociologist and network scientist, published a widely read article in which he explored the social networks of the American Revolution. He applied technical network analysis to membership lists of secret colonial societies. Which name was central among 1770s Colonial social networks? Yes, Paul Revere.

${ }^{103}$ Lazer, David, et al. “Computational Social Science,” Science, 6 February 2009, Vol. 323 no. 5915 pp. 721723. doi: 10.1126/science.1167742. Available at: http://www.sciencemag.org/content/323/5915/721.full

${ }^{104}$ Page, Lawrence; Brin, Sergey. “The Anatomy of a Large-scale Hypertextual Web Search Engine,” Computer Networks and ISDN Systems, 1998. doi: 10.1016/S0169-7552(98)00110-X. Available at: http://www.sciencedirect.com/science/article/pii/S016975529800110X 
${ }^{105}$ Solis, Brian. "Report: The Rise of Digital Influence and How to Measure It,” March 21, 2012. Available at: http://www.briansolis.com/2012/03/report-the-rise-of-digital-influence/

${ }^{106}$ http://www.empireavenue.com/about/ourstory Retrieved: May 18, 2014.

107 Solis, Brian. "Report: The Rise of Digital Influence and How to Measure It.”

${ }^{108}$ My thanks to Jeffrey Seglin of the Harvard Kennedy School for his insights on this issue and sharing his personal experience.

${ }^{109}$ Romero, Daniel M., et al. "Influence and Passivity in Social Media,” Proceedings of the 20th International Conference Companion on World Wide Web, 2011. Available at: http://dl.acm.org/citation.cfm?id=1963250

${ }^{110}$ Karpf, David A. "Social Science Research Methods in Internet Time,” Information, Communication \& Society, Vol. 15, Issue 5, 2012. doi: 10.1080/1369118X.2012.665468. Available at: http://www.tandfonline.com/doi/abs/10.1080/1369118X.2012.665468. In terms of this formulation, Karpf is riffing off of “Campbell's Law," which makes the same case for all quantitative social data. See: http://en.wikipedia.org/wiki/Campbell\%27s law

${ }^{111}$ Brian Solis, "Report: The Rise of Digital Influence and How to Measure It.”

112 Bilton, Nick. “Friends, and Influence, for Sale Online,” New York Times, April 20, 2014. Available at: http://bits.blogs.nytimes.com/2014/04/20/friends-and-influence-for-sale-online/.

${ }^{113}$ Alex Remington, product manager at the Washington Post, points out in a May 28, 2014, email exchange on this point that even as the value of influence metrics decays over time, there is nevertheless a window in which the value will be significant. He writes: "It will likely occur like this: 1) A metric of influence becomes widely adopted. 2) People optimize for it, because they realize that there is significant short-term rent or surplus to be captured by doing so. 3) People realize that the metric no longer measures anything meaningful, because the values that it measures have been artificially manipulated by rent-seekers. So they find a new metric - but they keep the money they already made. Repeat stages 2 and 3. The point is, there is significant money to be made in the interim, and time arbitrage should not be dismissed out of hand - entire businesses can be built from it. But if I'm right about steps 1-3, the other significant outcome of this is that it will tend to dampen the number of possible winners and to reinforce the tendency of a relatively small number of gatekeepers capable of spending the amount of money it takes to be able to win on the Internet. Anyone with the capital to win social by one metric will theoretically be able to spend that success to win it by the next metric. Sure, a disruptor might enter the sector, but the number of serious players is still likely to be small."

${ }^{114}$ Watts, Duncan J. Everything Is Obvious: How Common Sense Fails Us. (Random House, New York, N.Y., 2012), p. 104.

${ }^{115}$ Garthwaite, Craig; Moore, Tim. "The Role of Celebrity Endorsements in Politics: Oprah, Obama, and the 2008 Democratic Primary.” Department of Economics, University of Maryland (2008). Available at: http://www.stat.columbia.edu/ gelman/stuff_for_blog/celebrityendorsements_garthwaitemoore.pdf.

${ }^{116}$ Author interview via email with Sarah Marshall.

${ }^{117}$ Author interview via email with Patrick Cooper.

${ }^{118}$ Author interview with James Fowler.

${ }^{119}$ Goel, Sharad, et al. “The Structural Virality of Online Diffusion,” Microsoft Research, 2013.

${ }^{120}$ Author interview with Sharad Goel, March 25, 2014.

${ }^{121}$ Freelon points out in a May 20, 2014, email that "[a]nother issue here is that not all viral sharing phenomena can be measured using readily available trace data. People copy-paste things, store them in Google docs, share them over private systems like email and Twitter DMs, etc.”

${ }^{122}$ Author interview via email with Clay Shirky.

${ }^{123}$ Ibid. 
${ }^{124}$ Cheng, Justin, et al. “Can Cascades be Predicted?” Proceedings of the 23rd International Conference on World Wide Web, 2014. Available at: http://cs.stanford.edu/people/jure/pubs/cascades-www14.pdf.

${ }^{125}$ Nahon, Karine; Hemsley, Jeff. Going Viral, p. 16.

${ }^{126}$ Watts, Duncan J.; Peretti, Jonah. "Viral Marketing for the Real World,” Harvard Business Review, May 2007. Available at: http://hbr.org/2007/05/viral-marketing-for-the-real-world/ar/1.

${ }^{127}$ Author interview with Duncan Watts.

${ }^{128}$ Benkler, Yochai; Roberts, Hal; Faris, Robert; Solow-Niederman, Alicia; Etling, Bruce. "Social Mobilization and the Networked Public Sphere: Mapping the SOPA-PIPA Debate," Berkman Center Research Publication No. 2013-16, July 19, 2013. Available at: http://www.niemanlab.org/2013/07/social-mobilization-and-thenetworked-public-sphere-mapping-the-sopa-pipa-debate/.

${ }^{129}$ Graeff, Erhardt; Stempeck, Matt; and Ethan Zuckerman, “The Battle for 'Trayvon Martin’: Mapping a Media Controversy Online and Off-line," First Monday, 2014. doi: http://dx.doi.org/10.5210/fm.v19i2.4947.

${ }^{130}$ Hindman, Matthew. The Myth of Digital Democracy.

${ }^{131}$ Copps, Michael. “Net Neutrality Delayed, Net Neutrality Denied,” Common Blog, Sept. 16, 2013. Available at: http://www.commonblog.com/2013/09/16/net-neutrality-delayed-net-neutrality-denied/.

${ }^{132}$ Author interview with Eric Newton, April 9, 2014; via email April 29, 2014. 